\title{
A Review on the Phytoconstituents and Related Medicinal Properties of Plants in the Asteraceae Family
}

\author{
Jonathan I. Achika ${ }^{1}$, David Ebuka Arthur ${ }^{1}$, Igelige Gerald ${ }^{1}$, Adebiyi Adedayo ${ }^{2}$. \\ ${ }^{1}$ Department of Chemistry, Ahmadu Bello University Zaria. \\ ${ }^{2}$ Sheda Sci. and Tech. complex FCT, PMB 186 Garki Abuja
}

\begin{abstract}
The Asteraceae family of plants is a widely distributed medicinal plant throughout the world and has been used since ancient time. Members of this family have been used traditionally as astringent, antipyretic, anti-inflammatory, hepatoprotective, diaphoretic in fevers, smooth muscle relaxant, nerve tonics, laxatives and for the treatment of wounds, bleedings, headache, pains, spasmodic diseases, flatulence, dyspepsia dysentery, lumbago, leucorrhoea, hemorrhoids, gangrenous ulcer and disorders causing cachexia.Phytochemical investigations of the Asteraceae family have revealed that many components from this family are highly bioactive. There are many reports on the mentioned herbal effects. Although, the medicinal properties ofplants belonging to the Asteraceae family are recognized worldwide, there is no review article mainly about the structures of the phytochemical constituents of the plant of the asteraceaefamily. The present paper reviews the medicinal properties alongside with peculiar phytoconstituent of various plants belonging to the Asteraceae family. Various medicinal effects of these plants may be due to the presence of a broad range of secondary bioactive metabolites such as flavonoids, phenolic acids, coumarins, terpenoids (monoterpenes, sesquiterpenes, diterpenes, and triterpenes) and sterols which have been frequently reported from the Asteraceae family.
\end{abstract}

Keywords: Antioxidant, Asteraceae, bioactive compounds, hepatoprotective, phytochemical

\section{Introduction}

Asteraceaeous plants are distributed throughout the world and most common in the arid and semi-arid regions of subtropical and lower temperate latitudes. These plants typically have hairy and aromatic leaves and flat clusters of small flowers on the top of the stem. Since these flowers have various colors, a number of species are popular garden plants. The majority of the Asteracea family members are as the medicinal plants which have therapeutic applications. These comprise Achillea, Carthamus, Chromolaena, Emilia, and Pluchea.

There are no review papers on the different aspects of asteracea as a noteworthy and medicinal family. Recently, Saeidnia et al published a review article mainly about the structures of phytochemical constituents and a brief section of biological properties of Achillea species. Literature reviews show that there are many reports on pharmacological, immunological, biological and other therapeutic activities of these valuable herbs belonging to the asteraceae family which are reviewed in this article.

\subsection{Phytochemical Screening}

Preliminary phytochemical screening revealed the presence of glycoside, flavonoids, tannins, mucilage, carbohydrate and reducing sugarin tridaxprocumbenslinn.In Baccharisracemosa, the main phytoconstituents were sabinene, $\beta$-pinene, myrcene, limonene, $\delta$-cadinene, nerolidol, viridifloral, $\alpha$-muurolol and $\alpha$-cadinol. Alsobaccharislinearisphytoconstituentswere $\alpha$ - and $\beta$-pinene,myrcene, limonene, bicyclogermacrene, $\delta$ cadinene, caryophyllene oxide, cubenol and $\alpha$-cadinol. Yield on the Baccharisobovataoil was $2.82 \%$ and themain constituents were $\alpha$-thujene, $\alpha$ - and $\beta$-pinene, sabinene, myrcene, limonene and terpinen-4-ol (figure 1) [1]. Leaves from another Argentinian Baccharisspecies, Baccharistenelia were collected from the Lanos region of La Riojafor analysis of theessential oil composition.Spathulenol (figure 2) was the major component (2934\%) of the oil [2].Characteristic diterpenic constituents from the Baccharisgenus are the neo-clerodane type diterpenes, although kaurane and labdane derivatives have also been isolated. From Bacharrisgaudichaudiana, new clerodanediterpenoids, gaudichanolides A and B (figure 3), and a new ent-clerodanediterpene named bacchariol (Figure 4) were isolated [3]. The first anti-spasmodic flavonoids, cynarosideI (figure 4) andcosmosiin II (figure 5) were isolated from AchilleamillefoliumL. [4].

The main constituents of the safflower carthamustinctoriusL. arecarthamin and carthamidin. Other constituentsare safflor yellow, arctigenin, tacheloside, N-feruloyltryptamine, N-feruloylserotonin, steroids, flavonoids, and polyacetylenes.Carthamin is responsible for producing water-insoluble red dye and carthamidin forwater-soluble yellow colour dye[5]. The principle colouringcomponent of marigold flower Tageteserectais lutein, a fat-solublecarotenoid, which is responsible for the yellow toorange colour of the dye [6]. 


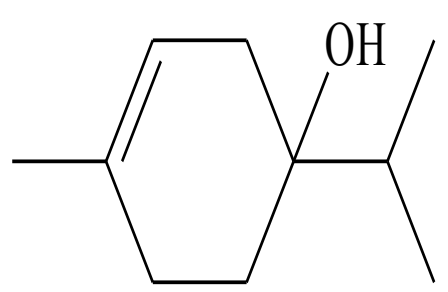

Fig. 1Structure of terpinen-4-ol.

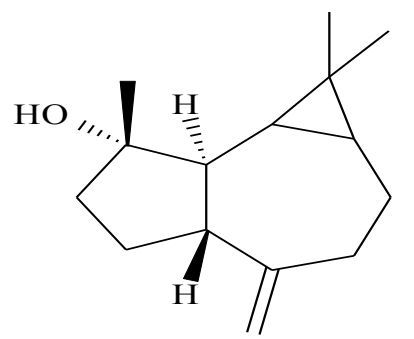

Fig. 2 Structure of spathunol<smiles>CC1(C)C(=O)C[C@@]2(C)COC(=O)C2=CCC[C@]1(C)CCC1COC(=O)C1</smiles>

Fig.3Gaudichanolide<smiles>Cc1cc2oc(-c3ccc(O)c(O)c3)c(O)c(=O)c2c(O)c1C</smiles>

fig. 4Cyniriside 1<smiles>CC1=CC(O)CC(C)(C)C1/C=C/C(C)=C/C=C(C)/C=C/C=C/C=C(C)/C=C/C=C(C)/C=C/C1=C(C)CC(O)CC1(C)C</smiles>

Fig. 6structure of lutein<smiles>Cc1cc(O)c2c(=O)c(O)c(-c3ccc(O)c(I)c3)oc2c1</smiles>

Fig 5cosmosiin

\section{Medicinal Properties Of Asteraceae Family}

\subsection{Wound healing activity}

Aqueous extract of the flowers of Achilleakellalensisapplied topically, has shown significant wound healing activity in rats. The wound sizes of the test compared to control groups were reduced faster [7]. This is due to the activity of flavonoids. Extracts from the leaves of Chromolaenaodoratahave been shown to be beneficial for treatment of wounds. In traditional usage, the leaf is ground into a paste and is applied topically on affected places to heal wounds [8]. The aqueous extract and the decoction from leaves of this plant have been used throughout Vietnam for the treatment of soft tissue wounds and burns for decades. A product made from Chromolaena named eupolin have already been licensed for use in Vietnam for soft tissue burns and wounds.

\subsection{Protective activity}

The protective activity of natural antioxidants in biological systems has received attention. Some medicinal plants have proved free radical scavenging or antioxidant activities [9].The infusions of Achilleaspecies were tested on antioxidant enzyme systems of erythrocytes and AchilleafalcataL. was the most effective one against CAT (catalase), GPx (glutathione peroxidase) and SOD (superoxide dismutase) enzyme systems of erythrocytes.Among the plant infusions, hig.........hest activities on leucocyte enzymes were by Achillecrithmifolia and AchilleanobilisL. subspecieaneilrechiion CAT, by Achilleamillefoliumsubspecies pannonicaon SOD, by AcholleateretifoliaWilld. OnGPx and by Achillea. Nobilissubspecies sipyleaon LPO (lactoperoxidase). Therefore, Achilleaspecies may be of potential sources of natural antioxidants for treatment or prevention of related diseases [10].

The influence of the extracts of A. alexandri-regis on hydroxyl and superoxide radicals' quantity in different in vitro systems have been determined. The ethyl acetate extract exhibited hydroxyl radical scavenging activity in all tested biological systems (liver homogenate, hemolyzed blood, serum and post mitochondrial liver fraction), whereas butanol extract reduced hydroxyl radicals significantly only in the post mitochondrial liver fraction (a 
homogenate of liver cells remaining after sedimentation of the mitochondrial fraction by centrifugation). Both extracts affected only hemolysed blood [11]. The hydroalcoholic extract of A. santolinaL. was studied on various in vitro antioxidative systems and it has been reported that the extract prevented formation of thiobarbituric acid reactive substances in $\mathrm{Fe}^{2+}$ ascorbate induced lipid peroxidation in rat liver tissue. Free radical induced protein oxidation has also been suppressed significantly by high concentration $(1000 \mu \mathrm{g} / \mathrm{ml})$ of the extract [12].Ethanol extracts of eight wild samples of A. ligusticaand one sample of cultivated A. millefoliumwere evaluated for radical scavenging activites including DPPH test. The TEAC (the concentration of a Trolox solution having an antioxidant capacity equivalent to that of the diluted hydroalcoholic extract) were in the range of 4.18 and $12.3 \mathrm{mM}$. The ability of the extracts to inhibit non-enzymatic lipid peroxidation using an in vitro system of linoleic acid oxidation has been investigated. Five of the nine extracts had a protective effect at the lowest tested amount $(5 \mu \mathrm{g})$. Protection on $\mathrm{CaCo}-2$ intestinal cells against $\mathrm{TBH}$-induced toxicity was also investigated and two of the tested ethanolic extracts of A. ligusticashowed protection against the oxidative stress. The antioxidant capacity and cytoprotective activity of A. collina. infusions against oxidative stress were investigated by chemical (DPPH and FolinCiocalteu assay) and biological assays (in vitro model of cytotoxicity and lipid peroxidation in PC12 cells line) and it has been shown that the infusions of leaves had the highest antioxidant and cytoprotective activity, where antioxidant capacity was significantly correlated with the total phenolic content but not with the cytoprotective profile [13].

\subsection{Esterogenic activity}

A crude extract of the aerial parts of A. millefoliumhas shown estrogenic activity [14]. Evaluation of the isolated and identified compounds from this plant indicated that luteolin andapigenin were the most important estrogenic compounds among tested compounds.Many phytoestrogens appear to have a stronger binding affinity with $\beta$ estrogen receptors than estradiol [15]

\subsection{Anti-diabetic activity}

The effect of A. santolina(hydro alcoholic extract) on blood glucose level, serum NO (nitric oxide) concentration and the oxidative stress in rat pancreatic tissue have been evaluated[16].Baccharis floribunda H.B.K. (Niquitao) is used in Venezuela as decoctions or infusions ofleaves and stems for skin infections, diabetes and rheumatism. BaccharisgaudichaudianaD.C. (Chilcamelosa) is used in Paraguay as a folk medicine for the treatment of diabetes and as a tonic and for the relief of gastrointestinal ailments [2].

\subsection{Antispermatogenic effect}

Ethanolic (intraperitoneally) and hydroalcoholic extracts (orally) of A. millefoliumwere administered to Swiss mice to evaluate the effect on spermatogenesis. The extract treated animals had an increased number of metaphases in the germ epithelium which should be due to substances stimulating cell proliferation [17].

\subsection{Antioxidant activity}

The nitric oxide scavenging activity of the Chromolaenaodorataextract was demonstrated. Quantitative determination of the total phenolic content shows that the extract contains an appreciable amount of phenolic compounds and may be responsible for the observed antioxidant potential [18].

The fresh juice and the methanolic extract ofemilliasonchifolia had potent inhibitory effects on hydroxyl radical formation and superoxide radical generation invitro. The results indicate that pre-treatment withPluchealanceolataattenuates cadmium chloride induced oxidative stress and genotoxicity by alteringantioxidant enzymes and reducing chromatid breaks and micronuclei formation [19].Extracts from Plucheaindicawere screened for flavonoid content, total phenolics, andantioxidant activity. PlucheaindicaLess. Extracts inhibited linoleic acid oxidation and had theDPPH, ABTS, and ferric cyanide antioxidant capacities. Therefore, the plant may contribute todietary antioxidant intake [20]. The aqueous ethanol extracts of Plucheaarabicashowedthe inhibition of DPPH radical at $89-93 \%$, after $15 \mathrm{~min}$ of incubation at a test concentration of50 g/ml. The total antioxidant capacity as gallic acid equivalents of $1790 \mathrm{mg} / \mathrm{g}$ of ethanolextracts were obtained for P. crispain the phosphomolybdenum assay [21]

\subsection{Trypanocidal Activity}

Four compounds active against the epimastigote forms of Trypanosomacruzi, the causativeagent of Chagas' disease, were isolated from the hexane extract of PlucheaquirocL.(Compositae). The flavone casticin, identified on the basis of its spectroscopic characteristics [22].

\subsection{Antiulcer activity}

The methanolic fraction of root extract was found to possess significant antiulceractivity in different experimental animal models. The extract also afforded significant protection tochemically-induced duodenal 
lesion in guinea pigs [23]. Significant enhancement of healing processin acetic acid-induced chronic gastric lesions was also observed in the P. indicaextract-treated animals[20].Baccharisgrisebachii, the aerial parts of this shrub, in the Andean provinces in Argentina, are recommended in infusion to treat gastric ulcers, as a digestive, local antiseptic and cicatrizant[2].Reviewing literature reveals that A. millefoliumshowed effectiveness in protecting the gastric mucosa against acute gastric lesions induced by ethanol and indomethacin and in healing chronic gastric lesions induced by acetic acid $\left(\mathrm{ED}_{50}=32 \mathrm{mg} / \mathrm{kg}\right.$, orally)[24] .Oral administration (30, 100 and $300 \mathrm{mg} / \mathrm{kg}$ ) of the hydroalcoholic extract inhibited ethanol-induced gastric lesions by 35, 56 and $81 \%$, respectively. Oral treatment with this extract $(1$ and $10 \mathrm{mg} / \mathrm{kg}$ ) reduced the chronic gastric ulcers induced by acetic acid by 43 and $65 \%$, respectively, and promoted significant regeneration of the gastric mucosa after ulcer induction denoting.The effects of aqueous ethanol extract of A. wilhelmsiion rat's gastric acid output in basal, vagotomized (VX), and vagal-stimulated conditions have been investigate. The extract showed a reduction in the acid output in vagal-stimulated condition at doses of 1 and $2 \mathrm{mg} / \mathrm{kg}$, which were not statistically significant [25].

\subsection{Gastro intestinal disease}

Emilia sonchifolia root juice is used to treat diarrhea by the Nepalese,the chinesee make use of the leaf tea to treat dysentery and in Africa it is consumed as vegetable for the treatment of stomach ailments [26].Baccharisconferta is used in the region of Veracruz, Mexico, totreat stomachaches. It is also recommended for use as a laxative and for stimulating urination [2].BaccharisgaudichaudianaD.C. (Chilcamelosa) is used in Paraguay as a folk medicine forthe treatment of diabetes and as a tonic and for the relief of gastrointestinal ailmentsBaccharisheterophyllaisethnomedically used in the stateof Queretara, Mexico, for alleviating gastrointestinal disorders. The plant is used in the form ofinfusions or decoctions of the aerial parts.Baccharisvaccinoides (Chilco) is one of the most popular remedies from the Chiapas region of Mexico for gastrointestinal disorders. The plant is used in the form of infusions or decoctions of the whole plant [2].

\subsection{Cytotoxicity effect}

The main constituents of are safflower(CarthamustinctoriusL.)carthamin and carthamidin. The chief constitsuentCarthaminhas uterine stimulating, coronary dilating andhypotensive properties. It also has the cytotoxic, antigenic and anti-platelet activity [27].There are some reports about the anti- proliferative activity of the isolated constituents from A. falcataand A. clavennae. L. These compounds have been found to decrease keratinocyte cell viability significantly. Statistical analysis confirmed an enhanced potency of the $\beta$-OH iso-secotanapartholide over the $\alpha, \beta-\mathrm{OH}$ diastereoisomeric mixture. The enhancement of the lipophilicity of the molecule resulted in the highest potency [28]The aerial part of A. clavennaewas used for isolation of the phytoconstituents and the antiproliferative activity of the compounds was tested to HeLa, K562 and Fem-X human cancer cell lines. Guaianolides, $9 \alpha$-acetoxyartecanin andapressin showed significant cytotoxic effects in all tested cell lines. A bisabolene, inducumenone exhibited a moderate activity. The most active compound was a flavonol, centaureidin, which was already known as cytotoxic agent [29].Cytotoxicity of the Chromolaena extract was also studied. These studies have demonstrated the presence of some compounds in the extract such as acacetin (5, 7- dihydroxy- 4'- methoxy flavone) and luteolin (5, 7, 3', 4'- tetrahydroxyflavone) which expressed activity against human small cell lung cancer and human breast cancer[30].

\subsection{Immunosuppressive activity}

The immunosuppressive potential of $50 \%$ ethanolic extract (PL) of Pluchealanceolataand itsbioactive chloroform fraction (PLC) was investigated with basic models of immunomodulation, The findings revealed thatP. lanceolatacauses immunosuppression by inhibiting Th1 cytokines [31].The aqueous extract of $\mathrm{A}$. talagonica was studied on humoral antibody responses in BALB/c mice and albino rabbits. Intraperitoneal administration of the extract to mice, prior to immunization with sheep red blood cells, resulted in a significant dose dependent decrease in haemagglutinating antibody (HA) titer in rabbits after intrascapular injection of the extract, a significant decrease in typhoid-H antibody (anti-HD) titer was found, but no change was observed in secondary response [32]. Methanol and aqueous methanol $(80 \%$ and $50 \% \mathrm{v}$ : v) extracts of A. talagonicahave been examined to find its immunosuppressive components. Guided by anti-SRBC (sheep red blood cells) assay, active principles were isolated by chromatographic methods and identified as choline, quercetinand caffeoylglucoside. These compounds compared to the control groups decreased anti-SRBC titer significantly. Alongside these compounds, 3'-methoxy luteolin and prolinehas been also reported from this plant [33]. Methanol extract and some other fractions of A. millefoliumwere studied on humoral immunity in BALB/c mice by microhaemagglutination test. Only two fractions showed a significant decrease in the anti- SRBC titer of mice. The immunological properties may be related to presence of glycosylated derivatives of caffeic acid, because caffeic acid glucosidewas isolated and identified from the active fractions. Some known compounds including, luteolin 7-O-glucoside and apigenin 7-O-glucoside have also been reported from this species [34].Effects of the essential oils of A. talagonicaand A. millefoliumhave been studied on humoral immune 
responses in $\mathrm{BALB} / \mathrm{c}$ mice. The oil isolated from $\mathrm{A}$. millefoliumssp. millefoliumpossessed a high percentage of sesquiterpenes (55.4\%) in which bisabolol was the main compound. The volatile oil of A. millefoliumdecreased the anti-SRBC antibody titer, but the oil of A. talagonicawas not effective. High percentage of sesquiterpenes and presence of proazulene in A. millefoliumtogether with the lack of these compounds in A. talagonicacould account for the different immunological effects of these plants [35].

\subsection{Biological effects}

Ethyl acetate extract of A. talagonicashowed toxicity in BST (brine shrimp lethality test) and on the basis of results only 5- hydroxy 3', 4', 6, 7- tetra methoxy flavone XXVII (Scheme 1) showed toxicity $(\mathrm{LC} 50=15 \mu \mathrm{g} / \mathrm{ml}$ ) against Artemiasalinalarvae [33]. It is reported that the essential oil of A. biebersteinii exhibited antimicrobial activity against 8 bacteria, 14 fungi and one yeast namely $\mathrm{C}$. albicans, whereas methanolicextract was inactive[36].The antimicrobial activity of the essential oil of A. ligusticawas evaluated by the broth micro-dilutimethod on 6 microbial strains and it showed to be effective against Streptococcus mutans [36]. In another report, antibacterial activity of the extracts (hexane: ether: methanol=1:1:1) of the aerial parts of A. clavennae, A. holosericeaSm., A. lingulataand A. millefoliumwere evaluated against five bacteria (S. aureus, E. coli, K. pneumoniae, P. aeruginosaand Salmonella enteritidis) and two fungi (A. nigerand C. albicans) and it was found that the extracts of all four species possessed a broad spectrum of antimicrobial activity against all tested strains [37].

Activity of nineteen Jordanian plants against multidrug-resistant E.colihas been reported. The methanolic extract of A. santolina(one of 19 species) was combined with antibiotics of different classes (chloramphenicol, neomycin, doxycycline, cephalexin and nalidixic acid) and tested against both the standard and resistant strain of E. coli. The results showed that the activity of all tested antibiotics especially doxycycline on the resistant strain was enhanced when it was used in combination with plant material. The enhanced activity of cephalexin against the standard strain has been reported to be higher than resistant strain[38]. The minimum inhibitory concentration (MIC) of the methanol extract of A. millefoliumis reported as $50 \mu \mathrm{g} / \mathrm{ml}$ [39]. In another study, the ethyl acetate extracts of A. talagonicaand A. tenuifoliashowed a moderate activity against the epimastigotes of T. cruzi[40].A. fragrantissimashowed the highest antiviral activity (among these species) against POLIO in a concentration dependent manner at complete non-toxic concentration range $(10-100 \mu \mathrm{g} / \mathrm{ml})$ and the highest detected antiviral activity was recorded at Rf of 106 . It seems that the interesting antiviral activity of A. fragrantissimaagainst POLIO may be attributed to of essential oil content which has been traditionally used as an antiseptic agent [41]. A new ionone glucoside, biebersteiniside, together with four known compounds 6-epiroseoside, ascaridole, strictic acid and centipedic acid were reported from the aerial parts of A. biebersteinii. The compounds were reported for the first time from A. biebersteinii. Also, antifungal activity was observed from the compounds[42].

\subsection{Antispasmodic activity}

The antispasmodic effects of Achilleaspecies might be due to the flavonoid constituents of the plant. Galangin ,quercetin and eupatilin, which are found commonly in Achillea, are reported to cause a potent relaxation of the ileumgaudichanolide [43]. The effect of A. millefoliumhydro-alcoholic extract on the contractile responses of the isolated guinea-pig ileum at five concentrations ranging from 0.05 to $5 \mathrm{mg} / \mathrm{ml}$ has been reported. Changes in contraction of tissues were monitored using force displacement transducer amplifier connected to physiograph. Each segment served as its own control. Results showed that the contractile response was inhibited by extract in a dose-dependent manner $(\mathrm{EC} 50=1.5 \mathrm{mg} / \mathrm{ml})$. Those results demonstrated that in vitro evaluation of A. millefoliumextract resulted in inhibition of electrical induced contractions of the guineapig ileum [44].

\subsection{Anti-inflammatory activity}

BacchariscoridifoliaD.C. (Mio-Mio, Romerillo) is used externally as an anti-inflammatory [2].The aqueous extract and dichloromethane extract of Plucheasagittalisproduced a total inhibition of $50.85 \%$ and $41.16 \%$ respectively. This study shows that the aqueous and dichloromethane extract of Plucheasagittalishad an anti-inflammatory effect in the carrageenan-foot oedema test [45].The methanol extracts of Emilia sonchifolia leafs found to inhibit carrageenan inducedodema indicating its Anti-inflammatory activity. [26] The influence of the methanol fraction of PlucheaindicaLess root extract (PIRE) was evaluatedin vivo for anti-inflammatory activity. PIRE produced significant anti-inflammatory activityagainst glucose oxidase induced paw oedema [46].The anti-inflammatory and antinociceptive activities of the ethanolic extract (EE) from aerial parts of PlucheaquitocDC. (Asteraceae) were evaluated in mice and rats. Oral treatment withthe EE (1-2 g/kg, p.o.) decreased the paw oedema induced by carrageenan in rats, showed antinociceptiveeffects on the tail-flick test and on acid-induced writhing in mice, and inhibited bothphases of pain (neurogenic and inflammatory) of the formalin test in rats. Topical application(EE $1.25,2.5$ and $5.0 \mathrm{mg}$ ) inhibited the ear oedema induced by croton 
oil in mice. The resultssupport the folkloric use of the plant in inflammatory processes[47]. Theethanolic extract of Pluchealanceolataexhibited significant anti-inflammatory activity, which was further investigated after fractionation. The result showed that activity was localizedin the hexane fraction, from which 1-taraxasterol acetate was isolated which proved to be one ofthe active constituents. Taraxasterolacetate, isolated from hexane fraction, accounted for onlypart of the activity of that fraction. It is obvious that there are other active substances present inthe hexane fraction which need to be isolated and characterized [48].Neolupenol, a pentacyclictriterpene isolated from Pluchealanceolataflowers, was studied todetermine its anti-inflammatory activity against carrageenin-induced rat-paw edema. The degreeof edema inhibition was found to increase with dose as well as time interval and was found to be maximum at $300 \mathrm{~min}$. Neolupenol, when administered at 100 $\mathrm{mg} / \mathrm{kg}$, p.o. was found to exhibit $70 \%$ edema inhibition which was greater than that of the reference compound, ibuprofen $(50 \mathrm{mg} / \mathrm{kg}$, p.o., $65 \%$ inhibition, and $300 \mathrm{~min})$ [49]

Besides the alkamides, as the noteworthy active anti-inflammatory compounds, sesquiterpenes are introduced as another effective group of the secondary metabolites. The methylene chloride - methanol extract of aerial parts of A. coarctatawas investigated by chromatographic analysis and resulted in isolation of two new guaiane acid derivatives, $1 \alpha, 6 \alpha, 8 \alpha$-trihydroxy-5 $\alpha, 7 \beta \mathrm{H}$-guaia-3,10(14),11(13)-trien-12-oic acid and $1 \alpha, 6 \alpha, 8 \alpha$ trihydroxy-5 $\alpha, 7 \beta \mathrm{H}$-guaia-3,9,11(13)-trien-12-oic acids, in addition to three known compounds, ligustolide-A , arteludovicinolide-A and austricin XL [50]. They also reported that the compounds and enhanced the proliferation of beneficial macrophages significantly and compounds exhibited anti-inflammatory properties (Hegazi et al., 2008). Another article has reported that chromatographic separation on dichloromethane extract

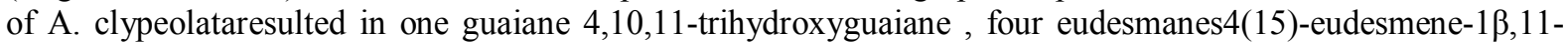
diol , clypeotriol, 3-epi-clypeotriol, cryptomeridiol, one diterpenesugereosideand two phenolicscentaureidin and scopoletin XLVII . The compounds XLI and XLVI have been reported for the first time [51].

\subsection{Venom Neutralizing Capacity}

The methanol root extracts of Plucheaindica(Less) were explored for the first time forneutralization of snake venom (Viperurussellii) activity. The P. indicaroot extracts significantlyneutralized the viper venominduced lethality and haemorrhagic activity in albino rat and mouse. Venom-induced coagulant and anticoagulant activity was also antagonized by both the extracts. No precipitating bands were observed between the plant extract and polyvalent snake venomantiserum. These observations confirmed that certain Indian medicinal plants like Plucheaindicapossess significant snake venom neutralizing capacity and need further examination for theiractive constituents [23].

The neutralization of viper and cobra venom by $\beta$-sitosterol and stigmasterol isolated from theroot extract of P. indicaLess. (Asteraceae) was evaluated in experimental animals. Cobravenom-induced lethality, cardiotoxicity, neurotoxicity, respiratory changes and PLA2 activitywere also antagonized by the active component. It potentiated commercial snake venomantiserum action against venom-induced lethality in male albino mice. The active fraction could

antagonize venom-induced changes in lipid peroxidation and superoxide dismutase activity. Thisstudy suggests that $\beta$-sitosterol and stigmasterol may play an important role, along withantiserum, in neutralizing snake venom induced actions [52]

\section{Conclusion}

Some of these traditional and folk usages have been evaluated showing the potential medicinal use of the plant. The medicinal properties of Asteraceaeare worldwide recognized and the plant is included in the national Pharmacopoeias of countries such as Germany, Czech Republic, France and Switzerland. As it is reviewed in this paper, antioxidant and protective activity of the Asteraceaeis reported frequently. This might be due to high content of flavonoids and phenolics in these plants. It is noteworthy that oxidative stress is produced under diabetic condition and plant like achilleamillefolium (asteraceae) is considered for high hypoglycemic activity. Among the medicinal properties of Achillea, their cytotoxic and antiulcer effects are important especially when the species contain immunomodulatory constituents. The activity of these plants against different bacteria, fungi and parasites might be due to the presence of a broad range of secondary active metabolites such as flavonoids, phenolic acids, coumarins, terpenoids (monoterpenes, sesquiterpenes, diterpenes, triterpenes) and sterols which have been isolated. Finally, presence of anti-inflammatory compounds such as sesquiterpenes and alamedas is another reason for importance of these plants as the potential source of medicinal compounds and drugs in future 


\section{References}

[1]. Tapia, A., Rodríguez, J., Theoduloz, C., Lopez, S., Feresin, G. E. and Schmeda-Hirschmann, G.Preliminary phytochemical activity of the pluchea species .Journal of. Ethnopharmacology(2004);95, 155.

[2]. Maria J. A., and Paulina B.Baccharis(Compositae): a review update. marigold petals. Journal of Food Science(2007); 41,163-164.

[3]. Guo, Y., Li, Y., Xu, J., Watanabe, R., Oshima, Y., Yamakuni, T. and Ohizumi, Y.. Preliminary Phytochemical and Antimicrobial screening of BucharrisgaudichaudianaJournal of Natural Product(2006); 69: 274.

[4]. Falk, A. J., Smolenski, S. J., Bauer, L. and Bell, C. L.. Isolation and identification of three new flavones from AchilleamillefoliumL. Journal of Pharmaceutical Sciences(2000);64: 1838-1842.

[5]. Kizil, S., Çakmak, S., Kirici, M. and Inan, A. Comprehensive study on safflower (carthamustinctoriusL.) In semi-arid conditions. Journal of biotechnology(2008);12: 23

[6]. Philip, T., and Berry, W. Process for the purification of lutein-fatty acid esters from tegeteserecta. Phytotherapy Research(2000);9:145.

[7]. Pirbalouti, A.G., Koohpayeh, A., Karimi, I. The wound healing activity of flower extracts of Punicagranatumand Achilleakellalensisin Wistar rats. Acta Pol Pharm.(2000);67: 107-110.

[8]. Ayyanar, M. and Ignacimuthu, S. Herbal medicines for wound healing among tribal people in Southern India: Ethnobotanical and Scientific evidences. International Journal of Applied Research in Natural Products(2009);2(3): 29-42.

[9]. Mantle, D., Eddeb, F. and Pickering, A.T. Comparison of relative antioxidant activities of British medicinal plant species in vitro. Journal of Ethnopharmacy(2000);72: 47-51

[10]. Konyalioglu, S. and Karamenderes, C.The protective effects of Achillea L. species native in Turkey against H2O2-induced oxidative damage in human erythrocytes and leucocytes. J Ethnopharmacolog(2005);102: 221-227

[11]. Kundakovic, T., Mimica, T., Dukic, N. and Kovacevic, N. Free radical scavenging activity of Achilleaalexandri-regisextracts. Fitoterapia(2005);76: 574-576.

[12]. Ardestani, A. and Yazdanparast, R. Antioxidant and free radical scavenging potential of Achilleasantolinaextracts. Food Chemistry(2007);104: 21-29.

[13]. Giorgi, A., Bombelli, R., Luini, A., Speranza, G., Cosentino, M., Lecchini, S. and Cocucci, M. Antioxidant and cytoprotective properties of infusions from leaves and inflorescences of AchilleacollinaJ Ethnopharmacolog(2009);104: 21-29

[14]. Schulz,V., Hansel, R. and Tyler, V.E. In: Rational Phytotherapy: A Physician's guide to Herbal Medicine: Springer(2001); 12 P 294.

[15]. Innocentia, G., Vegetob, E., Dall-Acquaa, S., Cianab, P., Giorgettia, M., Agradib, E., Sozzib, A., Ficoc, G. and Tomec, F. In vitro estrogenic activity of AchilleamillefoliumL. Phytomedicine(2007);14: 147-152.

[16]. Yazdanparast, R., Ardestani, A. and Jamshidi, S.Experimental diabetes treated with Achilleasantolina: Effect on pancreatic oxidative parameters. Journal of Ethnopharmacy(2007);112: 13-18.

[17]. Montanari, T., De Carvalho, J.E. and Dolder, H. Antispermatogenic Effect of AchilleamillefoliumL. in Mice. Contraception(2005);58: 309-313.

[18]. Alisi, C. S. and Onyeze, G.O. Nitric oxide scavenging ability of ethyl acetate fraction of methanolic leaf extracts of Chromolaenaodorata(Linn.). African Journal of Biochemistry Research(2008);2 (7): 145-150.

[19]. Jahangir, T.T.H., Khan, L., Prasad, S., and Sultana B..Anti oxidant activity of the Pluchea genus Journal of Pharmacy and Pharmacology(2005); 57119

[20]. Andarwulan, N.R., Batari, D.A., Sandrasari, B., Bolling, H. and Wijaya, A. Total phenolics and Antioxidant activity of Plucheaindica. Food Chemistry(2010); 12: 34

[21]. Marwah, R.G., Fatope, M.O., Mahrooqi, R.A., Varma,G.B. and Abadi, H. Total phenolics and Antioxidant activity ofPluchea Arabica. Food Chemistry(2007);101: 465.

[22]. Zani, C.L., Alves, T.M., Oliveira, A.B.D., Murta, S.M.F., Ceravolo, R .I and Romanha, I J. Phytoconstituent and antimicrobial activity ofPlucheaquitocPhytotherapy Research (1994); 13, 375.

[23]. Alam, M.I., Auddy, B. and Gomes, A. Preliminary phytochemical and antimicrobial activity of Plucheaindica. Phytotherapy Research(2000);10: 58

[24]. Cavalcanti, A.M., Baggio, C.H., Freitas, C.S. Rieck, L., De Sousa, R.S., Da Silva-Santos, J.E., Mesia-Vela, S., and Marques, M.C.A. Safety and antiulcer efficacy studies(Darul(2006); 17: 37-41.

[25]. Niazmand, S.,Khooshnood, E. andDerakhshan, M. Effects of Achilleawilhelmsiion rat's gastric acid output at basal, vagotomized, and vagal-stimulated conditions. Pharmacognosy Mag(2010);6: 282-285.

[26]. Muko, K.N. and Ohiri, F.C . A Preliminarystudy on the anti-inflammatory properties of Emilia sonchifolia leaf extract. Fitoterapia(2000);71 (1); 65-8

[27]. Chengaiah, B.K., Mallikarjuna, R.A, Mahesh, M., Alagusundaram, C. and Madhusudhana, M.Medicinal importance of natural dyes. International Journal of Pharmaceutical Technology Research (2010); 2(1):144-154.

[28]. Ghantous, A., Nasser, N., Saab, I., Darwiche, N. and Saliba, N.A. Structure-activity relationship of seco-tanapartholides isolated from Achilleafalcatafor inhibition of HaCaT cell growth. European Journal of Medicinal Chemistry(2009); 44: 3794-3797

[29]. Trifunovic, S., Vajs , V., Juranic, Z., Zizak, Z., Tesevic, V., Macura, S. and Milosavljevic, S. Cytotoxic constituents of Achilleaclavennaefrom Montenegro. Phytochemistr (2006);68: 887-893.

[30]. Suksamrarn, A., Chotipong, A., Suavansri, T.,Boongird, S., Timsuksai, P., Vimuttipong, S. and Chuaynugul, A. Antimycobacterial activity and cytotoxicity of flavonoids from the flowers of Chromolaenaodorata. Arch Pharm Res.(2004);5(27): 507-511.

[31]. Mandeel, Q.A. andTaha, A. Preliminary phytochemical screening ofPluchea. lanceolata .Journal Pharmaceutical Biology(2005);43(4), 340 .

[32]. Rezaeipoor ,R., Saeidnia, S. and Kamalinejad, M. Immunosuppressive activity of Achilleatalagonicaon humoral immune responses in experimental animals. Journal of Ethnopharmacy. (2000); 65: 273-276.

[33]. Saeidnia ,S., Yassa, N., Rezaeipoor, R., Shafiee, A., Gohari, A.R., Kamalinejad, M., and Goodarzy, S. Immunosuppressive principles from Achilleatalagonica, An endemic species of Iran. Darul(2009); 17: 37-41.

[34]. Yassa, N., Saeidnia, S., Pirouzi, R., Akbaripour, M. and Shafiee, A..Three phenolic glycosides and immunological properties of Achilleamillefolium.Darul(2007);15: 49-52.

[35]. Saeidnia, S., Yassa, N. and Rezaeipoor,R.Comparative investigation of the essential oils of AtalagonicaBoiss and A millefoliumL, Chemical composition and immunological studies. J ournal of Essential Oil Research 2004; 16: 262-264.

[36]. Maggi, F., Bramucci, M., Cecchini, C., Coman, M.M., Cresci, A., Cristalli, G., Lupidi, G., Papa, F., Quassinti, L., Sagratini, G. and Vittori, S. Composition and biological activity of essential oil of AchillealigusticaAll. (Asteraceae) naturalized in central Italy: Ideal candidate for anti-cariogenic formulations.Fitoterapia(2009).80: 313-319. 
[37]. Stojanovic, G., Radulovic, N., Hashimoto, T. and Palic, R.In vitro antimicrobial activity of extracts of four Achilleaspecies. The composition of AchilleaclavennaeL. (Asteraceae) extract. Journal of Ethnopharm(2005);101185-190.

[38]. Darwish, R.M. and Aburjai, T.A. Effect of ethnomedicinal plants used in folklore medicine in Jordan as antibiotic resistant inhibitors on Escherichia coli. BMC Complement Alternative Medicine(2010); 10: 9.

[39]. Mahady, G.B., Pendland, S.L., Stoia, A., Hamill, F.A., Fabricant, D. Dietz, B.M. and Chadwick, L.R. In vitro susceptibility of Helicobacter pylori to botanical extracts used traditionally for the treatment of gastrointestinal disorders. Phytotherapy Research(2005); 19: 988-991.

[40]. Gohari, A.R., Saeidnia, S., Hadjiakhoondi, A., Naghinejad, A. and Yagura,T. Trypanocidal activity of some medicinal plants against the epimastigotes of Trypanosomacruzi. Journal of Medicinal Plants(2008);7: 44-48.

[41]. Soltan, M.M. and Zaki, A.K.Antiviral screening of forty-two Egyptian medicinal plants. Journal Ethnopharmacy(2009); 126: $102-$ 107.

[42]. Mahmoud, A.A. and Al-Shihry, S.S. A new ionone glucoside and terpenoid constituents from Achilleabiebersteiniiand their antifungal activity. Natural Product Community(2006);1: 697-703.

[43]. Hammad, H.M. and Abdalla, S.S.Pharmacological effects of selected flavonoids on rat isolated ileum: Structure-activity relationship. General Pharmacology. (2007); 28: 767-771.

[44]. Babaei, M., Abarghoei, M.E., Akhavan, M.M., Ansari, R., Vafaei, A.A., Taherian,A.A., Mousavi, S. and Toussy, J. Antimotility effect of hydroalcoholic extract of yarrow (Achilleamillefolium) on the guinea-pig ileum. Pakistan Journal of Biological Sciences. (2007)10: 3673-3677.

[45]. Perez, F.E., Marin, T. and Adzet,T. Preliminary phytochemical screening and anti microbial activity of Plucheasagittalis Phytotherapy Research,(2000);9:145.

[46]. Sen, T., Dhara, A.K., Bhattacharjee, S.S., Pal, S., Nag, A.K. and Chaudhuri A. Preliminary phytochemical and antimicrobial activity of Plucheaindica. Phytotherapy Research(2002);16, 331.

[47]. Barros, I.M., Lopes, 1., Borges, O., Borges, C., Ribeiro, N. and Freire, M. Preliminary phytochemical screening and anti microbial activity ofPlucheaquitoc .Journal of ethnopharmacy(2006); 14,34

[48]. Srivastava,V. N Varma, J.S. Tandon, R.C. and Srimal, A.Anti inflammatory activity ofPluchealanceolataInternational. Journal of Crude Drug Research., 2000; 28(2), 135

[49]. Kaith, B.S. Preliminary phytochemical and antimicrobial activity of PluchealanceolataInternational Journal of Pharmacognosy.(2000)34(1), 73 .

[50]. Hegazy, M.E.F., Abdel-Lateff, A., Gamal-Eldeen, A.M., Turky, F., Hirata, T., Pare, P.W. and Karchesy, J.K. Anti-inflammatory activity of new guaiane acid derivatives from Achilleacoarctata. Natural Product Community(2008);3: 851-856.

[51]. Werner, I., Mucaji, P., Presser, A. and Glasl, S. Sesquiterpenes and phenolic compounds from Achilleaclypeolata. Z Naturforsch $\mathrm{B}(2007) ; 62: 267-271$.

[52]. Gomes, A., Saha, A., Chatterjee, I. and Chakravarty, A.K. Preliminary phytochemical and antimicrobial activity of Plucheaindica .Phytomedicine(2007); 14: 637

\section{Bibliography}

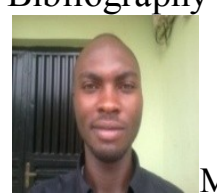

Mr. Achika Jonathan Ilemona is from Kogi State, Nigeria. He was born on the $6^{\text {th }}$ May 1987 into the home of Mr. and Mrs. BalaAchika, of which he is the fourth child. He is a graduate of chemistry from the Ahmadu Bello University Zaria, Kaduna State, Nigeria, (2009), from where he obtained a masters degree in Organic chemistry. He enjoys watching football and reading news during his leisure. He is friendly and hard working and desires to be a researcher and chartered chemical analyst.

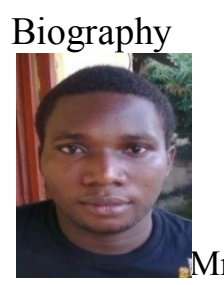

Mr. David Ebuka Arthur was born in Minna in 1986 and raised in Christian home. He is a Physical Chemist and a graduate of Ahmadu Bello University Zaria, where he obtained his Master and Bachelor's degree in chemistry.

David is the Eldest of four children born into the family of Mr. and Mrs. Arthur Emeanu; he enjoys reading up space articles online, when he is not working with some chemistry software.

As a Scientist David's desire is to further his carrier by accepting challenging responsibilities in a dynamic progressive course, that will create and maintain a friendly working environment and offer opportunity for growth. 